\title{
A Literature Review of Museum and Heritage on Digitization, Digitalization, and Digital Transformation
}

\author{
Han-Teng Liao ${ }^{1,2}$ Man Zhao ${ }^{1,2, *}$ Si-Pan Sun ${ }^{1}$ \\ ${ }^{1}$ School of Literatures and Communications, Sun Yat-sen University Nanfang College, Guangzhou, Guangdong, 510970, China \\ ${ }^{2}$ New Media Research Centre, Sun Yat-sen University Nanfang College, Guangzhou, Guangdong, 510970, China \\ *Corresponding author.Email: manzhao_zm@outlook.com
}

\begin{abstract}
Promising to enhance the performance and widen the reach of an organization, the notion of digital transformation demands higher-level socio-technical transitions that are beyond mere digitization of resources. The sector of museum and heritage, as the main cultural and educational organizations for humanity, has also recently discussed the topic of digital transformation as one of the main areas for research and policy. With the aim to explore how these related concepts (digitization, digitalization, digital transformation and dataification) have been discussed in the sector, this article conducts a scientometric analysis of 1,107 articles collected from the Web of Science (WoS) database. By examining the main sources and disciplines, through the lens of these keywords, it shows several research fronts (Information \& Computer Science; Humanities \& Sustainability Studies; Library Science, etc) and research topics (digital preservation, digital collection, document digitization, digital skills, etc). While the specific literature on digital transformation remains small and sparse, the overall research attention has begun to shift from technology-centric concerns to people-centric concerns. The paper provides the first systematic review for curators, educators, researchers, and policymakers in the sector to leverage both the digital and organizational resources for more sustainable livelihood.
\end{abstract}

Keywords: socio-technical systems, digital museums, digitalization, digitization

\section{INTRODUCTION}

The sector of museum and heritage has recently begun to discuss the notion of digital transformation as the main area of research and policy. For instance, the world's leading organization in the museum and heritage sector, the International Council of Museums (ICOM)'s International Committee for Documentation (CIDOC) has set the research agenda for its 2020 Call for Papers on the theme of "Digital transformation in cultural heritage institutions", arguing that the digital tools "have gradually transformed, sometimes revolutionized, our very concept of documentation, and from there, of collection management, conservation, study and dissemination"[1].

Indeed, the related concepts digitization, digitalization, and dataification have been discussed in improving the performance and reach of cultural institutions such as museum and other heritage organizations such as galleries, galleries libraries, and archives. Such digitization efforts have been facilitating the preservation, dissemination and valorization of such cultural and educational resources, ranging from the 3-d digitization[2], digital data processing and storage[3], representation and reproduction of objects [4]. Also, as the society has become more digitized, the museum industry has recognized the importance of digital transformation [5] [6].

However, there is currently a little systematic review of this research area, and such review on the concepts of digitization, digitalization, datafication and digital transformation in relation to museum and heritage research is essential to inform museum and cultural heritage development for both research and practices.

\section{DATA AND METHODS}

To systematically collect relevant literature, the search query below was executed on the Web of Science (WoS):

TS = ("digiti*ation" OR "digitali*ation" OR "digital transformation" OR "datafication") AND TS = (museum* OR heritage)

Our search topics (see TS above) covers different spelling of digitization and digitalization. With the scope of several indexes (SCI-EXPANDED, SSCI, A\&HCI, CPCI-S, CPCISSH, ESCI), total 1107 articles were collected on March 6, 2020, and then visualized and analyzed using VOSviewer and Python scripts we have developed to clean the data.

\section{RESEARCH FINDINGS}

As shown in Figure 1, the year of 2014 marks a milestone for the increasing number of publications. Before 2014, the number of publications has been growing to over 50 per year. Since 2015, it has increased rapidly, and 158 papers have been published on the topic in 2019 . 


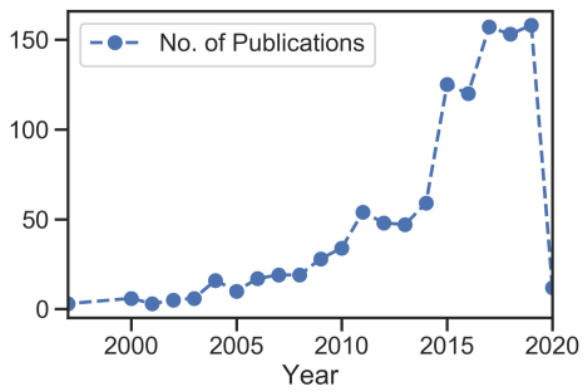

Figure 1 The number of publications

\subsection{Main clusters of publication venues and disciplines}

To explore the latest digitization development of museum and heritage research, the main publication venues, disciplines, and keywords are presented as follows.

\subsubsection{Clusters of publication venues}

Showing where digitization/digital transformation work has been published and discussed, Figure 2 and Table 1 shows the main research clusters (or research fronts[8]) on the network based on bibliographic coupling. Before describing each cluster, it is worth mentioning that the six clusters of publication sources are shown to have a core network, linking to other five clusters, as shown in, Figure 2. The size of a publication node represents how many articles a given publication has published, and the width of the links between nodes represent the measurement of bibliographic coupling. Also, each in the "Publication Venues" column in Table 1 is shown with their respective rankings based on the number of articles published

Table 1 Detailed information of top publication sources based on bibliographic coupling relationship network

\begin{tabular}{|c|c|c|}
\hline \multicolumn{2}{|r|}{ Cluster (of disciplines) } & Publication Venues \\
\hline$\# 1$ & $\begin{array}{l}\text { Multidisciplinary Core } \\
\text { (Imaging Science, } \\
\text { Remote Sensing, } \\
\text { Computer Science, } \\
\text { Archaeology, } \\
\text { Geography, etc.) }\end{array}$ & $\begin{array}{l}\text { (1) IEEE Conferences, (3) Journal of Cultural Heritage, (4) Digital Heritage International } \\
\text { Congress, (6) CIPA Symposium, (7-1) ISPRS Congress, (7-2) ISPRS 3D-Arch, (8) CIPA- } \\
\text { ICOMOS-ISPRS Symposium, (9-1) In Situ-Revue De Patrimoines, (9-2) ACM Journal on } \\
\text { Computing and Cultural Heritage, (10-1) Virtual Archaeology Review, (11-2) Euromed } \\
\text { Digital Heritage, (12) International Conference on Virtual Systems and Multimedia, (14-4) } \\
\text { International Technology, Education and Development Conferenc, (15-6) International } \\
\text { Congress on Archaeology, Computer Graphics, Cultural Heritage and Innovation, (15-2) } \\
\text { Mediterranean Archaeology \& Archaeometry, (16-7) Multimedia Tools and Applications }\end{array}$ \\
\hline$\# 2$ & $\begin{array}{l}\text { Information \& } \\
\text { Computer Science }\end{array}$ & $\begin{array}{c}\text { (2) IS\&T Archiving Conference, (11-1) Profesional De La Informacion, (14-1) ACM } \\
\text { Conferences, (16-6) Libri }\end{array}$ \\
\hline \#3 & $\begin{array}{l}\text { Humanities \& } \\
\text { Sustainability Studies }\end{array}$ & $\begin{array}{l}\text { (14-2) Sustainability, (14-3) Archeologia E Calcolatori, (15-4) International Journal of } \\
\text { Intangible Heritage, (15-5) International Journal of Heritage Studies }\end{array}$ \\
\hline \#4 & Library Science & $\begin{array}{l}\text { (13) Electronic Library, (14-5) Program-Electronic Library and Information Systems, } \\
\text { (16-3) Digital Cultural Heritage, (16-4) Journal of Documentation }\end{array}$ \\
\hline \#5 & $\begin{array}{l}\text { Zoology and } \\
\text { Biodiversity }\end{array}$ & $\begin{array}{c}\text { (5) Zookeys, (15-1) Plos One, (15-7) Biodiversity Data Journal, (16-8) ACM+IEEE } \\
\text { Conferences }\end{array}$ \\
\hline \#6 & $\begin{array}{l}\text { IFLA (Information \& } \\
\text { Library Science) }\end{array}$ & $\begin{array}{l}\text { (15-3) Bosniaca-Journal of the National and University Library of Bosnia and Herzegovina, } \\
\text { (16-2) IFLA Journal-International Federation of Library Associations }\end{array}$ \\
\hline
\end{tabular}

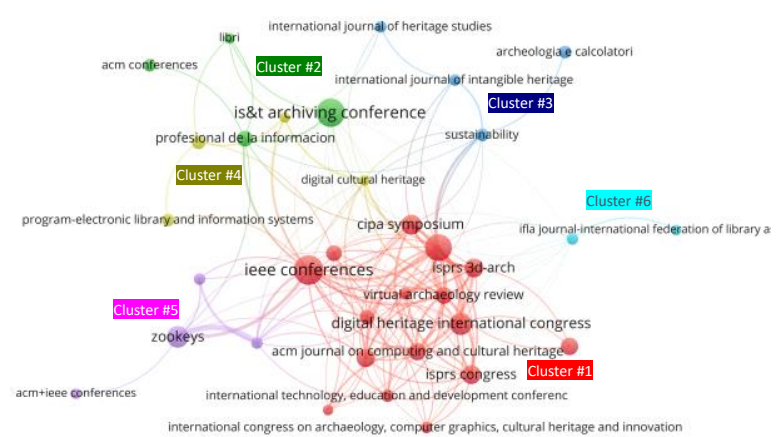

Figure 2 Visualization of top publication sources based on bibliographic coupling relationship network.
Cluster \#1, as shown at the main core in Figure 2 in color red, and the first row in Table 1, includes a wide range of disciplines, ranging from Imaging Science, Remote Sensing, Computer Science, Archaeology, to Geography, with top publication venues such as (1) a collection of IEEE Conferences, (3) Journal of Cultural Heritage, (4) Digital Heritage International Congress, (6) CIPA Symposium, (10-1) Virtual Archaeology Review, etc. Note that main IEEE conferences include e-Science, Big Data, etc.

Cluster \#2, as shown at the upper left in Figure 2 in green, contains largely "Information and Computer Science" publication venues such as (2) IS\&T Archiving Conference, (11-1) Profesional De La Informacion, (14-1) ACM Conferences, and (16-6) Libri. The ACM conferences include topics such as virtual reality, digital libraries, etc. 


\subsection{Keyword co-occurrence maps}

Cluster \#3, "Humanities and sustainability research", in the 2) Sustainability, (14-3) Archeologia E Calcolatori, (15-4) International Journal of Intangible Heritage, and (15-5) International Journal of Heritage Studies.

Cluster \#4, the "Library Science" cluster, as shown in Figure 2 in yellow color, is at the intersection among almost all other clusters, with top venues such as (13) Electronic Library, (14-5) Program-Electronic Library and Information Systems, (16-3) Digital Cultural Heritage, and (16-4) Journal of Documentation. Cluster \#5, the "Zoology and Biodiversity" cluster is shown at the lower left in purple.

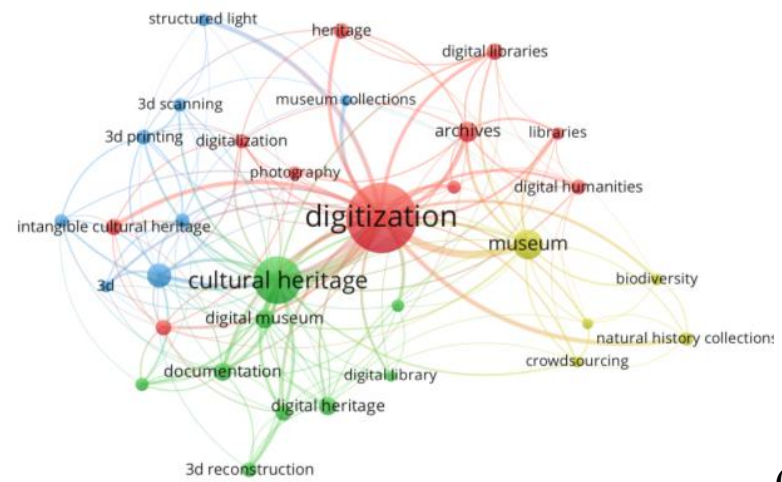

(a)
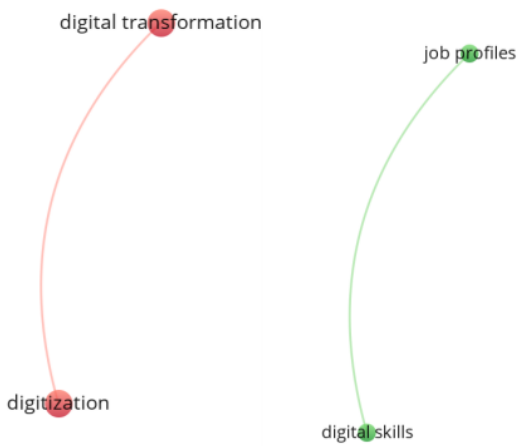

(c)

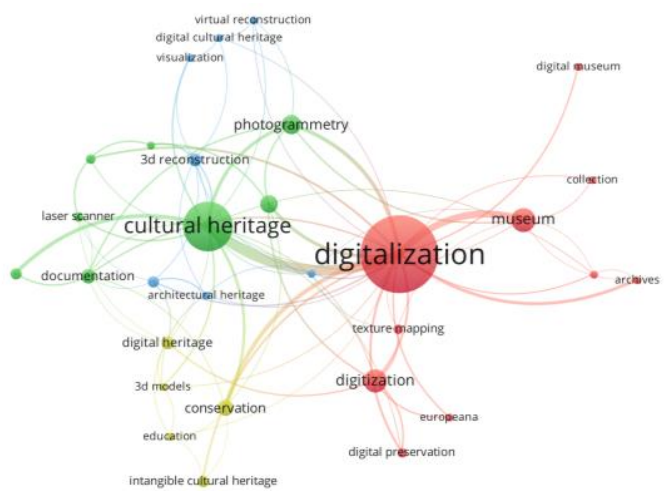

(b)

With the aim to explore how different the related concepts (such as digitization, digitalization, digital transformation and dataification) are, the research conducted a series of keyword co-occurrence maps for respective notions of digitization. Such findings should indicate not only how these concepts differ, but also how these concepts relate to other concepts and/or topics.

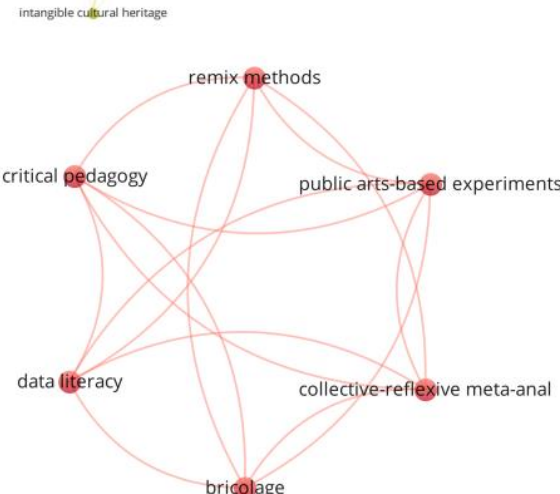

(d)

Figure 3 A map based on keyword co-occurrence (based on author keywords): (a) digitization dataset, (b) digitalization dataset (c) digital transformation dataset, and (d) datafication dataset.

Figure 3 shows that (a) digitization and (b) digitalization datasets contain richer content (i.e. more articles and thus related keywords), and such finding is also evidenced by the number of items each dataset has (see also Table 2). In contrast, (d) datafication and (c) digital transformation datasets contain much less content, but they are also much recent. Also, the concepts of digitization and digitalization are associated with technologies such as 3D technologies, whereas those of data transformation and datatification, are associated with people-related concepts such as data literacy and digital skills.

Table 2 Descriptive statistics and outcomes

\begin{tabular}{ccccc}
\hline & No. & Years & Main Topics & Features \\
\hline $\begin{array}{c}\text { Digitiza- } \\
\text { tion }\end{array}$ & 879 & $\begin{array}{l}1997- \\
2021\end{array}$ & $\begin{array}{l}\text { 3D technologies, } \\
\text { cultural heritage, } \\
\text { digital libraries, } \\
\text { digital museums }\end{array}$ & $\begin{array}{c}\text { Collections } \\
\text { digitized as } \\
\text { resources }\end{array}$
\end{tabular}

\begin{tabular}{ccccc}
$\begin{array}{c}\text { Digitali- } \\
\text { zation }\end{array}$ & 229 & $\begin{array}{c}1997- \\
2020\end{array}$ & $\begin{array}{c}\text { 3D technologies, } \\
\text { cultural heritage, } \\
\text { digitization, }\end{array}$ & $\begin{array}{c}\text { Streamlined as } \\
\text { digital processes }\end{array}$ \\
$\begin{array}{c}\text { Digital } \\
\text { transfor- } \\
\text { mation }\end{array}$ & 21 & $\begin{array}{c}2004- \\
2021\end{array}$ & $\begin{array}{c}\text { digital skills, } \\
\text { job profiles }\end{array}$ & $\begin{array}{c}\text { Revolutions, } \\
\text { and transitions } \\
\text { designed }\end{array}$ \\
$\begin{array}{c}\text { Datafica- } \\
\text { tion }\end{array}$ & 1 & 2020 & $\begin{array}{c}\text { data literacy, } \\
\text { critical pedagogy, } \\
\text { remix methods }\end{array}$ & $\begin{array}{c}\text { Behaviors and } \\
\text { actions datafied }\end{array}$ \\
\hline
\end{tabular}

Overall, the related literature on digital transformation remains small and sparse. Still, the notion of digital transformation appears to take on a more organizational, human capacity, and human resource approach. For instance, the processes of digital transformation in cultural organizations have been discussed for its workforce[9] and for shaping design spaces for collaboration [10]. For 
Committee for Documentation (CIDOC). (2020). http://network.icom.museum/cidoc.

[2] L. Gomes, O. Regina Pereira Bellon, L. Silva, 3D reconstruction methods for digital preservation of cultural heritage: A survey, Pattern Recognition Letters. 50 (2014) 3-14.

https://doi.org/10.1016/j.patrec.2014.03.023.

[3] V. Blagoderov, I.J. Kitching, L. Livermore, T.J. Simonsen, V.S. Smith, No specimen left behind: industrial scale digitization of natural history collections, Zookeys. (2012) 133-146. https://doi.org/10.3897/zookeys.209.3178.

[4] F. Soler, F.J. Melero, M.V. Luzón, A complete 3D information system for cultural heritage documentation, Journal of Cultural Heritage. 23 (2017) 49-57. https://doi.org/10.1016/j.culher.2016.09.008.

[5] Axiell, Digital transformation in the museum industry, 2016. https://www.axiell.com/report/digitaltransformation-in-the-museum-industry/ (accessed March 8, 2020).

[6] M. Zhao, X. Wu, H.-T. Liao, Y. Liu, Exploring research fronts and topics of Big Data and Artificial Intelligence application for cultural heritage and museum research, in: AIBDA, Guangzhou, China, 2019.

Altogether, the review overall signals a shift in research attention from technology-centric concerns to peoplecentric concerns. Museum and heritage professionals expect more beyond mere technologies; they start to expect the social impact of technologies.

The digital transformation and datafication aspects of our daily life present renewed challenges to both educational and cultural resources skills and future jobs. The findings presented here lay the groundwork with a systematic mapping so that educators, researchers and policymakers can use as a roadmap to identify both opportunities and challenges facing the development of heritage-related digital changes.

\section{ACKNOWLEDGMENT}

The research is funded by a project of $\mathrm{HCI}$ for Education Development (2018WQNCX283), under the 2018 Major Projects of Guangdong Province Department of Education "Young Innovative Talents" Grants, People's Republic of China.

\section{REFERENCES}

[1] CIDOC, Call for papers: Digital transformation in cultural heritage institutions, ICOM's International
[7] J. Saltz, M. Skirpan, C. Fiesler, M. Gorelick, T. Yeh, R. Heckman, N. Dewar, N. Beard, Integrating Ethics within Machine-learning Courses, ACM Trans. Comput. Educ. 19 (2019) 1-26. https://doi.org/10.1145/3341164.

[8] E. Garfield, Research fronts, Current Comments. (1994).

[9] A. Silvaggi, F. Pesce, Job profiles for museums in the digital era: research conducted in Portugal, Italy and Greece within the Mu.SA project, ENCATC Journal of Cultural Management and Policy. 8 (2018) 56-69.

[10]G. Arrigoni, T. Schofield, D.T. Pisanty, Framing collaborative processes of digital transformation in cultural organisations: from literary archives to augmented reality, Museum Management and Curatorship. (2019). https://doi.org/10.1080/09647775.2019.1683880.

[11]S.Z. Lacedelli, M. Tamma, F. Fazzi, Digital education as a catalyst for museum transformation: the case of the "Museums and New Digital Cultures" course, ENCATC Journal of Cultural Management and Policy. 9 (2019) 47-65. 